International Journal of English Language Studies (IJELS)

ISSN: $2707-7578$

DOI: $10.32996 /$ ijels

Website: https://al-kindipublisher.com/index.php/ijels

\title{
Literary Embodiment on the Levels of Comprehension in the "Balak"
}

\author{
Kiven Meco R. Luzano \\ Master of Arts in Education, English, Senior High School Teacher, Sogod National High School, Division of Southern Leyte, \\ Philippines
}

$\square$ Corresponding Author: Kiven Meco R. Luzano, E-mail: kime_luzano@yahoo.com

\section{ARTICLE INFORMATION ABSTRACT}

Received: 17 September 2021

Accepted: 16 October 2021

Published: 30 October 2021

DOI: 10.32996/ijels.2021.3.10.4

\section{KEYWORDS}

Literary Embodiment, Levels of Comprehension, "Balak", Reader Response
This study claimed that the local poem, known as "Balak" contained aspects that could be used in teaching reading and in assessing the reading comprehension level of students. This study used a descriptive-interpretive type of research. It is anchored on Reader-Response Criticism facilitated through focus-group discussion, and duly validated through investigator triangulation. Ten collected local poems ("Balak") were analyzed using Barrett's five levels of comprehension: literal, reorganization, inference, evaluation, and appreciation. It was found out that the ten "Balak" could be used as a tool for reading and assessing reading comprehension because it contained embodiments of the different levels of reading comprehension. Each "Balak" comprised contents fitted to the level and experience of the learners as manifested in how they connected and related with the ideas, emotions as well as situations portrayed in the text. It was also found out that in terms of reading comprehension level, the respondents were proficient in the literal level, beginning level in both the reorganization and inference levels, developing in the evaluation level, and proficient in the appreciation level. The ten "Balak" contained embodiments on the levels of reading comprehension which could be used as teaching tools in reading, more activities in the reorganization and inferential levels were to be emphasized. Based on the findings of the study, the following recommendations were formulated. Teachers should apply contextualization and localization in the teaching-learning process. They should also be aware that local literary pieces were good sources to develop students' reading abilities. It could be used as springboards for teaching strategies, reading comprehension assessment, and activities that encourage discussions and stimulate imaginative responses leading to well-rounded and interesting student interactions.

\section{Introduction}

People in all walks of life blended to unfold literature. Young, old, rich, and poor learned to pace across life and defined it because there were stories behind it that guided them in their journeys. As such, literature played an important part in our human existence. It widened and opened up our minds. It enabled us to preserve the culture, traditions, customs, and practices that we had many centuries ago and at the present time. It introduced us to the world of experiences. It helped us become knowledgeable and conscious of past events and situations of the people in a specific location. On the other hand, literary pieces are good sources of instructional materials. There are still aspects in the sphere of literature that need to be explored that might contribute to educational goals. With these considerations, it was the contention of this study that comprehension questions were embedded in local poems like "Balak" which can be used in teaching reading and in assessing the students' comprehension levels.

Well-renowned educator and reading expert Rasinski (2015) emphasized that a great difference in teaching reading can be achieved through poetry and song instruction. He further contended that poems brought significant and substantial progress to his reading class students in five weeks. Moreover, Hughs (2017) maintained the effect of poetry on the development of oral

Copyright: (C) 2021 the Author(s). This article is an open access article distributed under the terms and conditions of the Creative Commons Attribution (CC-BY) 4.0 license (https://creativecommons.org/licenses/by/4.0/). Published by Al-Kindi Centre for Research and Development, London, United Kingdom. 
language skills which was correlated with reading proficiency. On a cultural level, Mc Carthy (2009) made use of her students' poetic heritages through translation. The students translated the original poems and made their own versions of them. All of these practices in using poetry to improve reading comprehension were incorporated in the views of Kolk (2015) who emphasized that as a combined text of conciseness and purpose, reading and writing poems provided chances for learners at different levels.

With due considerations of the positive effects of using poetry on the comprehension levels of the learner, the Department of Education implemented Republic Act No. 10533, also known as "Enhanced Basic Education Act of 2013". It clearly stated in Section 10.2 (h) that "The curriculum shall be flexible enough to enable and allow schools to localize, indigenize, and enhance the curriculum based on their respective educational and social contexts." This law encouraged teachers to adapt and utilize local materials or literary pieces in their respective classes to enhance quality education; promote awareness with, and appreciation among the learners to local literary pieces of local writers as well.

However, teachers in the Department of Education found it difficult to adapt and incorporate localization in their classes because there were no available books or even collections of localized materials for teachers' use. It served as an additional burden to teachers because they needed to search and collect localized materials. Moreover, selecting and deciding for suitability and relevance equally demanded more of their effort and time. Thus, this study was conceptualized.

Through the enthusiasm and initiative of the Senior High School students and with the assistance of local folks in Libagon, Southern Leyte, ten local poems or "Balak" along with other local literary pieces were collected. Guided by the provisions of the levels of comprehension and reader-response criticism, the Grade 11 students analyzed the ten "Balak" collected. Such analysis determined the embodiment of the chosen "Balak" in terms of their usefulness in developing reading comprehension while determining the capacity of the students in the reading comprehension levels. The result of the analysis served as a guide in making an instructional blueprint when teaching and/or assessing the levels of reading comprehension of students

\section{Literature Review}

\subsection{Use of Local Literary Materials}

Enhancing the quality of educational delivery was the ultimate goal and rationale behind curriculum localization and the localization of schooling materials. UNESCO (2002) noted that "A crucial dimension of quality education was that of the relevance of curricula content; the diversity of local (sub-national), cultural, and socio-economic realities."

A key factor driving the localization of school curricula and the localization of schooling content was the ethnic and linguistic diversity of many nations. This diversity must be taken into account when designing school lessons, both in terms of local relevance and in terms of linguistic delivery, to create the vital links previously mentioned between learners and materials (UNESCO, 2002). This local delivery must be "associated with the natural environment, social environment, as well as the cultural and environmental needs of the region" (Thesia, 2012). In the Philippines, Sec.5 (d) and (h) in Republic Act 10533 also known as "Enhanced Basic Education Act of 2013" stipulated that the "curriculum shall be contextualized and global" (Official Gazzete, 2003, para. 22). In addition, it is also maintained that "the curriculum shall be flexible enough to enable and allow schools to localize, indigenize, and enhance the curriculum based on their respective educational and social contexts." (Official Gazzete, 2003, para. 26). For this reason, it is imperative that the teacher should look for the appropriate teaching materials in the locality.

\subsection{Reading Comprehension}

Reading materials must have undergone some methodological or theoretical considerations. Since this study emphasized reading comprehension levels, the researcher chose Barrett's (1968) taxonomy that took into account its literal, reorganization, inference, evaluation, and appreciation levels.

Level 1 comprised literal comprehension that focused on the ideas and information that were explicitly stated. A simple task in literal comprehension required recognition or recall of a single fact or incident. Level 2 focused on a reorganization that required students to analyze, synthesize, and/or organize ideas and information explicitly stated in the text. In this level, they paraphrased or translated the author's statements. Level 3 was inferential wherein the students used ideas and information explicitly stated; and intuition and personal experiences as the basis of conjecture and hypotheses. Their prior knowledge regardless of where it came from was an integral part of inference. In level 4, the emphasis was on evaluation in which the students dealt with judgments and focused on qualities of accuracy, acceptability, desirability, worth, or probability of occurrence. Level 5 was appreciation which allowed the students to be emotionally and aesthetically sensitive to the work and to have a reaction to the work of its psychological and artistic elements. It included both the knowledge of the emotional response to literary techniques, forms, styles, and structures.

Reading comprehension must be the basic consideration of all readers. The ability of the readers to understand what they were reading; interpret ideas and inject meaning to printed words was comprehension. Al-Khateeb (2010) emphasized that "reading 
comprehension was considered the real core for the reading process; and a big process around which all other processes were centered. Comprehension was the peak of the reading skills and the basis for all reading processes. He who did not comprehend what he read was considered as if he had not read." In addition, Ozdemir (2009) emphasized that reading comprehensively really affected the learner's education and his life as a whole. Learning in any lesson depended on the understanding of the learning instrument of that lesson; thus, a learner who could not read comprehensively found it difficult to be successful in his or her lessons.

In teaching reading comprehension, it was imperative for teachers to be sensitive and aware of the levels and capability of the learners to be able to choose and incorporate the right material that fits in their level and interest in order for them to sustain reading. Maples (2010) shared some frustrations when students could not understand what they read. He pointed out that those who struggled with comprehension often weakened their willingness to continue to read. This fact prompted educators to really check the reading comprehension of their students.

It has been proven by most teachers that reading comprehension separated the passive or unskilled reader from an active or skilled reader. Skilled readers were those who did not just read but interacted with the text while those unskilled readers simply read or parroted the letters and words. Moreover, the skill of reading comprehension increased the pleasure and effectiveness of reading. It also helped individuals interact in all other subjects as much as in their personal and professional lives.

Reading comprehension depended largely on how individuals process the words and the ideas in texts. It was critically important to the development of a student's reading comprehension. It allowed an active process that required an intentional and thoughtful interaction between the reader and the text. Comprehension was a necessary skill for proficient reading. However, learners may differ in the perception of things based on how they are perceived and what experiences they could connect to the reading materials. In some cases, reading comprehension was a challenge for some learners with learning and attention issues. McNamara et al. (2007) said that learners with problems with comprehension could not construct meaning from text. Reading comprehension involves at least two people: the reader and the writer. The process of comprehending involved decoding the writer's words and then using background knowledge to construct an approximate understanding of the writer's message. Otherwise, the difficulty of acquiring the skills made readers interpret an author's message in different ways.

Reading comprehension problems affect students which they might not be able to understand the words themselves (Bauman et al., 1992). Indeed, word decoding development and deficits were the concerns of many educators, particularly for basic education (McNamara, 2007). Best et.al (2005) believed that the said concerns sometimes led to the neglect of sentence comprehension. Numerous problems could occur for the reader at the comprehension level. Furthermore, McNamara (2005) upheld that "changes in reading strategies as a function of reading training" revealed that students' understanding of how the words came together in each sentence could be a challenge. The student might understand each word and even each sentence, but fail to understand the relationships between the sentences and the meaning of the text as a whole.

Through the use of varied resources, mentors could motivate students to learn. It was through reading where learners discovered things and recapitulated them in their own world. The use of literature in reading could be beneficial to learners, for it could be used as the basis for progression. Learners enjoyed using literature if mentors blended it with the so-called "technology" in the classroom. Their power to reorganize, make inferences, and develop an appreciation and the other styles would be restored and developed if they would apply this type of strategy.

Literature provided pleasure to listeners and readers. It offered a relaxing escape and leisure moments to their daily problems. Making time for recreational reading and using high-quality literature helped to develop enthusiastic readers and improved achievement (Block \& Mangieri, 2002). According to Rosenblatt (1995), "The power of literature to offer entertainment and recreation was still its prime reason for survival." Developing a love of literature as a recreational activity was possibly the most important outcome of a literature program.

Furthermore, Bacon (2010) avowed that "Literature built experience." (n.p.). Children expanded their horizons through vicarious experiences. They visited new places, gain new experiences, and met new people. They learned about the past as well as the present and a variety of cultures, including their own. They discovered the common goals and similar emotions found in people of all times and places. It could be expected of teachers to employ a variety of strategies in the classroom. One of these effective strategies in reading is the use of literature where they were required to enhance it to make learning meaningful to students.

\subsection{Reading Comprehension Strategies}


In reading comprehension, readers used different strategies. The difference in strategy was due to differences in attitudes and cognitive styles that the reader had in responding to the information in the reading text. This connection was based on the findings of Pfizer (n.d.) as cited by Sadeghi (2012) which showed that students who had an open nature and a free field learning style had a high score in understanding the reading text. Brown (2007) explained that learning strategies had a close relationship with the learning styles and self-factors or personalities of students. This was supported by Hazzard (2016) who explained that if the learning strategy was not in accordance with the learning style, students could not learn the language well. According to Brown (2007), language learning strategies could be grouped into three kinds: cognitive strategies, metacognitive strategies, and socio-affective strategies. The three kinds of strategies had variants in their use in language learning. It depended on the cognitive style and the learner's understanding of the strategy he or she occupied.

Gagne (1977) explained that cognitive strategy was an internal process known as the learning process of control. Furthermore, he explained that as an internal process, it served as a way to modify and regulate the learning process. He also argued that it became the basic structure for learning. The cognitive strategy of the learner always evolved in line with their success in learning.

The use of local literary materials in reading could also be applied using cognitive skills. Interpreting the text used in local materials could be very intricate. It would require the students to examine the words and lyrics of the "Balak" decorously in order to fully understand the meaning and essence of the "Balak".

The results of Rothkopf and Bisbicos' research cited by Gagne (1977) showed that by utilizing cognitive strategies, readers were able to control their attention in understanding a text. Furthermore, Block (1986) explained that in understanding a text, a cognitive strategy referred to how the reader sought to understand what they read, how to make the reading meaningful, and what to do if they encountered difficulties or problems. This strategy in practice could support or assist the reader in understanding the texts they read. It could also impede or undermine the understanding of the text (Cohen, 1986).

The use of cognitive strategy in understanding literary pieces could be an appropriate way to examine the meaning of the text. Readers may develop and enhance fully their reading ability and reading comprehension skills if they are used to practicing cognitive strategy. Improving the comprehension skills of children in interpreting literary pieces could be beneficial to the community because it can promote a better understanding of the norms and culture of the community they live.

\section{Methodology}

\subsection{Research Design}

This research utilized a descriptive-interpretive type of research. It is called descriptive - interpretive type because the methods rely on linguistic rather than numerical data. This was used to determine the literary embodiments on the aspects of reading comprehension of the ten collected local poems "Balak" as well as the students' capacity in dealing with questions patterned after Barrett's five levels of reading comprehension.

\subsection{Research Materials}

The study made use of the ten selected local "balak" of Libagon, Southern Leyte. These were collected by the Senior High School (Grade 11) students of RMSM Nahaong National High School who were officially enrolled in school year 2017-2018. The literary embodiments of these ten "balak" were analyzed by the Senior High School (Grade 11) students, following the provisions of Barrett's taxonomy of reading comprehension. The ten "balak" are 1.) "Kinabuhi sa Tawo", 2.) "Paninguha", 3.) "Balak sa Reyna", 4.) "Pagmahay" 5.) "Maloibon", 6.) "Pagpanguyab", 7.) "Ikaw Ra", 8.) "Pagtakas sa Bintana", 9.) "Pinangga", 10.) "Dughang Samaran".

Since the study aimed to determine the embodiment of the ten "Balak" as tools in teaching reading comprehension and identify the reading comprehension ability of the students, the researcher made use of Barrett's taxonomy in reading comprehension which was composed of five levels: literal, reorganization, inference, evaluation, and appreciation. These five levels served as the basis in contextualizing the questions for the ten "Balak". There were three questions for each level. The interview guides were taken from different sources.

\subsection{Research Environment}

This research was conducted at Libagon, Southern Leyte. It is a fifth class municipality in the province of Southern Leyte. It is approximately 22 kilometers from Sogod, Southern Leyte. It consists of 14 barangays namely: Biasong, Bogasong, Cawayan, Gakat, Jubas (Poblacion), Magkasag, Mayuga, Nahaong, Nahulid, Otikon, Pangi, Punta, Talisay (Poblacion), Tigbao. Libagon celebrates "Pangilis Festival" as tribute to the Lady of Mount Carmel held every $16^{\text {th }}$ day of July. This municipality is also known of its beautiful natural spots namely: Biasong Spring, Uwan-uwanan Falls, and Malipayon Shore. 
The researcher conducted the study in the said municipality to identify the local literary pieces in Libagon which were applicable and useful in the classroom and to promote awareness and appreciation among students, teachers, and the community of the municipality's local literary pieces.

\subsection{Research Participants}

The participants of this study were the Senior High School (Grade 11) students who were officially enrolled for Academic Year 2017-2018 of Rito Monte de Ramos Sr. Memorial Nahaong National High School. They were chosen as participants in the study because they studied literature as one of the course subjects in senior high school.

\subsection{Data Gathering Procedure}

The researcher required the Grade 11 Senior High School students to collect local literary pieces in their barangays in Libagon, Southern Leyte. Of the literary pieces collected, the researcher chose ten local poems "Balak" to be used in this study.

The researcher divided the Grade 11 Senior high school students into three groups of ten members after he had prepared the interview questions. Their grades in English were used in the heterogeneous grouping.

Focus Group Discussion was used in eliciting the answers of the students to the interview guides. It provided them with the opportunity to explain and expand their answers. Follow-up questions were also raised for the researcher to elicit more answers from the students.

Consequently, the researcher checked the answers of the respondents which were tabulated and consolidated in a matrix. It was forwarded for counter-checking to the three experts who were teachers in English and Literature.

The data gathered helped in establishing the embodiment of the ten "Balak" as a tool in teaching and assessing the students' reading comprehension level.

\subsection{Data Analysis Procedure}

The statistical treatments that the researcher used in this study were the following:

1. Average. It was used to get the mean score of the respondents for each question. To get the average, the researcher added the scores for each question then divided it by the total number of elements.

2. Percentage. It was used to express how large/small one quantity was relative to another quantity.

\section{Results and Discussion}

Table 1. Reading Comprehension Level Embodiment of "Kinabuhi sa Tawo"

\begin{tabular}{|c|c|c|c|c|c|}
\hline $\begin{array}{c}\text { Levels of } \\
\text { Comprehension }\end{array}$ & $\begin{array}{c}\text { No. of } \\
\text { Items }\end{array}$ & $\begin{array}{c}\text { Maximum } \\
\text { Score }\end{array}$ & $\begin{array}{c}\text { Average } \\
\text { Score }\end{array}$ & Percentage & Description \\
\hline Literal & 3 & 9 & 8 & $89 \%$ & Proficient \\
\hline Reorganization & 3 & 9 & 5 & $56 \%$ & Beginning \\
\hline Inference & 3 & 9 & 7 & $78 \%$ & Developing \\
\hline Evaluation & 3 & 9 & 6 & $67 \%$ & Beginning \\
\hline Appreciation & 3 & 9 & 9 & $100 \%$ & Advanced \\
\hline
\end{tabular}

Legend:

$\begin{array}{ll}\text { 90-above } & \text { - Advanced } \\ 85-89 & \text { - Proficient } \\ 80-84 & \text { - Approaching Proficiency } \\ 75-79 & \text { - Developing } \\ 74-\text { below } & \text { - Beginning }\end{array}$

*The rating scale for the levels of comprehension was based on DepEd Order No. 17, series of 2012.

Table 1 illustrates that the respondents in the "Kinabuhi sa Tawo" were proficient in the literal level, developing in inference level, and advanced in appreciation level. This implies that the respondents when exposed to "Balak" which talks about life and real situations can easily apprehend the meaning and appreciate the message because they can connect and relate their own views in life. The respondents appreciate "Kinabuhi sa Tawo" because it talks about life and the essence of human existence. They are able 
to relate their own thoughts and ideas that when a person died his or her memories will be remembered forever. The informants' personal connections to "Kinabuhi sa Tawo" are evident in their responses:

"I can relate to this "Balak" because it is true that even a person vanished on earth, he/she is still be remembered by you. This "Balak" made me remember my grandmother who is very close to me. Where my grandmother is going, there I was too. Even though I already forget of her death, this "Balak" really made me remember of her." (Participant 31)

"I can relate to this "Balak" the death of my beloved one. It is really hard for me to accept her death. I still remember her memories while she was still alive." (Participant 17)

According to Epstein (2018), "Motivated students are more excited to learn and participate." This simply means that teaching a class full of motivated students would be enjoyable for teachers and students alike. Some students are self-motivated with a natural love of learning. But even with those students who did not have this natural drive, a great teacher could make learning fun and inspire them to reach their potential.

On the other hand, the respondents are beginning in reorganization and evaluation levels which denote that they find it hard to restructure and to create their own version of the "Balak". They have difficulty in determining the technique in writing as well as in defining the central idea of the "Balak".

In this aspect, teachers must double their time in developing students' techniques in writing and formulating ideas. An article by Foley (2002) on Six Classroom Management Every Teacher Can Use stated that "Effective teachers are passionate about educating their students. They want to spend their time teaching, not dealing with classroom disruptions".

However, based on the results, "Kinabuhi sa Tawo" is an appropriate tool in teaching and assessing reading because it is suited to the level and experiences of the respondents. It gives equal opportunity for each student to react and to share his or her own perspective and experiences in relation to the content of the "Balak". It can also be a good source in promoting their confidence and in expressing the desired ideas or opinions to be understood by other students.

John Dewey (1916) as cited by McHale (2015) stressed that "Education is not preparation for life, education is life itself" (p.1). Life and education relate to each other. It is through education individuals acquired knowledge that opened the doors to a lot of opportunities. With that, teachers must teach and expose students to the contents which would greatly help them to survive in this world. This is one of the roles of education which is to provide a great deal of support to students for the development of their full potential.

Moreover, Thompson as cited by Ferlazzo (2014) maintained that "We need to provide our students with activities that are innovative and challenging as well as purposeful if we want them to be engaged in learning". This suggests that better outcomes are achieved when learners are provided with perplexing and delightful activities.

Table 2. Reading Comprehension Level Embodiment of "Paninguha"

\begin{tabular}{|c|c|c|c|c|c|}
\hline $\begin{array}{c}\text { Levels of } \\
\text { Comprehension }\end{array}$ & $\begin{array}{c}\text { No. of } \\
\text { Items }\end{array}$ & $\begin{array}{c}\text { Maximum } \\
\text { Score }\end{array}$ & $\begin{array}{c}\text { Average } \\
\text { Score }\end{array}$ & Percentage & Description \\
\hline Literal & 3 & 9 & 8 & $89 \%$ & Proficient \\
\hline Reorganization & 3 & 9 & 6 & $67 \%$ & Beginning \\
\hline Inference & 3 & 9 & 6 & $67 \%$ & Beginning \\
\hline Evaluation & 3 & 9 & 6 & $67 \%$ & Beginning \\
\hline Appreciation & 3 & 9 & 8 & $89 \%$ & Proficient \\
\hline
\end{tabular}

Legend:

$\begin{array}{ll}\text { 90-above } & \text { - Advanced } \\ 85-89 & \text { - Proficient } \\ 80-84 & \text { - Approaching Proficiency } \\ 75-79 & \text { - Developing } \\ 74-\text { below } & \text { - Beginning }\end{array}$

*The rating scale for the levels of comprehension was based on DepEd Order No. 17, series of 2012. 
Table 2 shows that in "Paninguha" the respondents were proficient both in the literal and appreciations levels. It indicates that the respondents have prior knowledge and experience about a man who exerts effort to win the heart of the woman. Their prior knowledge and experience help them determine the theme of the "Balak". It also helps them to understand easily the purpose and the message of the writer.

However, the respondents were at the beginning stage in the reorganization, inference, and evaluation levels. The result reveals that the respondents fall short in paraphrasing a "Balak" because they have limited knowledge of the structure, tone, theme, and technique in writing "Balak". The respondents' priority in learning is finding the moral lesson rather than restating the "Balak" with their own thoughts and feelings. Simply put, the respondents' responses are based on their own experiences. This is reflected in the following transcription:

"Ang pagpaninguha sa pagpanguyab mao ang paghatag ug sakripisyo ug respeto ug tungod niani nahimo ang paghigugmaay." (Participant 18)

"Moises is really correct that when you love a person you are not just until words but you need to have actions and effort". (Participant 10)

"Paninguha" can be considered a tool for reading and assessing the reading comprehension of the students because it fits their interests and age. It talks about a man who sought love and mercy from the woman he desired. Despite all his struggles and uncertainties, he did not lose hope and continued to strive to win the heart of his ladylove. This scenario enables the students to relate and connect their own experiences and ideas with courtship and love. The respondents are able to captivate the feelings and emotions in "Paninguha" because they are motivated to recapitulate the main idea of the "Balak". Relating "Balak" to real-life scenarios kindles students' emotions and feelings.

Aguilar (2013, para. 1) emphasized that "Poetry promotes literacy, builds community, and fosters emotional resilience. It can cross boundaries that little else can. Poetry builds resilience in kids and adults; it fosters Social and Emotional Learning. A well-crafted phrase or two in a poem can help us see an experience in an entirely new way. We can gain insight that had evaded us many times, that gives us new understanding and strength."

Furthermore, Yeats as cited by Watts (2017) contended that "It is blood, imagination, intellect running together. It bids us touch and taste and hear and see the world, and shrink from all that is of the brain only." Our schools are places of too much "brain" only. We must find ways to surface other ways of being, other modes of learning. We must also find ways to talk about the difficult and unexplainable things in life -- death and suffering and even profound joy and transformation" (page 11).

The respondents are able to associate things in the "Balak" especially that exposing them to simple ways and in the desired situation makes them effective at their own sense. They also negotiate things in a context that provides useful ideas to enable them to grow personally.

From this, teaching students requires teachers to employ simple strategies where students openly express their thoughts and feelings. Leblanc (1998) said, "Good teaching is as much about passion as it is about the reason. It is about caring for your craft, having a passion for it, and conveying that passion to everyone, most importantly to your students" (para. 1).

Similarly, Wirth, and Perkins (2008), as cited in the National Academies Press issued in 2015, "The reflection process not only leads to deeper and more effective learning but also lays the groundwork for being a self-directing learner" (p. 55). From this standpoint, the learners are motivated to learn the "Balak" because it portrays real-life experiences.

Table 3. Reading Comprehension Level Embodiment of "Balak sa Reyna"

\begin{tabular}{|c|c|c|c|c|c|}
\hline $\begin{array}{c}\text { Levels of } \\
\text { Comprehension }\end{array}$ & $\begin{array}{c}\text { No. of } \\
\text { Items }\end{array}$ & $\begin{array}{c}\text { Maximum } \\
\text { Score }\end{array}$ & $\begin{array}{c}\text { Average } \\
\text { Score }\end{array}$ & Percentage & Description \\
\hline Literal & 3 & 9 & 8 & $89 \%$ & Proficient \\
\hline Reorganization & 3 & 9 & 6 & $67 \%$ & Beginning \\
\hline Inference & 3 & 9 & 7 & $78 \%$ & Developing \\
\hline Evaluative & 3 & 9 & 6 & $67 \%$ & Beginning \\
\hline Appreciative & 3 & 9 & 9 & $100 \%$ & Advanced \\
\hline
\end{tabular}

Legend:

90-above - Advanced 


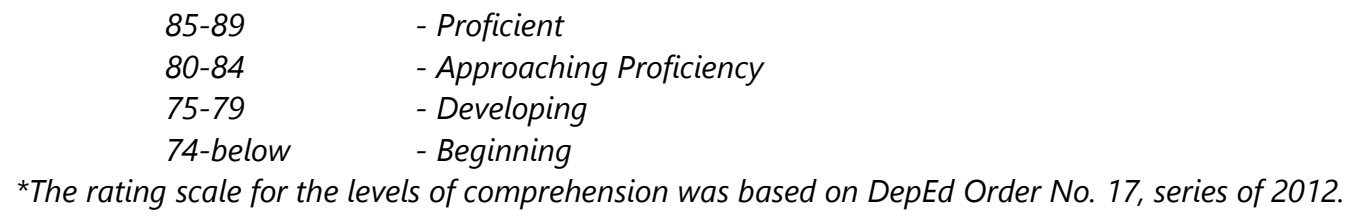

Table 3 illustrates that the respondents were proficient, developing, and advanced in the literal, inference, and appreciative levels respectively. This suggests that the respondents understand the purpose and the intention of the writer in writing the "Balak" which permits them to connect and appreciate it. They are able to relate their idea about love and courtship from their own personal experiences, hence, viewing the writer's desire to win the woman's heart leads them to reflect the writer's purpose and intention. They associate themselves with the character in the "Balak" and express their reactions to the perspective of the writer. A respondent (Participant 6) said, "I feel pity to the writer because he was being left in pain and crying."

On the other hand, the respondents were beginning in the reorganization and evaluation levels which reveal that they understand the purpose and intention of the writer but have difficulty in determining the theme, tone, techniques of writing, and the setting in the "Balak". They have a low score in restating the "Balak" in their own version because they were not able to identify the main idea and the essence of the "Balak". With the results, this "Balak" is a great tool for reading and assessing reading because it caters to the different reading levels of the students.

According to Brewer (2016), poetry helps by teaching rhythm. Singing words together with a beat helps cognitive understanding of words and where they fit. Additionally, it teaches children the art of creative expression, which most found highly lacking in the new-age educational landscape. In essence, poetry gives them a great tool for developing themselves and reading.

Amy Lowell, as cited by Singh, M.P. (2006), said, "Art is the desire of a man to express himself, to record the reactions of his personality to the world he lives in" (page 31). The writer conveyed that students achieve full understanding because they appreciate the expression and purpose of the author in the "Balak".

With the results, this "Balak" is a great tool for reading and assessing reading because it caters to the different reading levels of the students. The students can process, connect, and internalize the idea of the "Balak". Teachers must consider accommodating the students' learning styles to permit them to adjust easily to the "Balak".

Table 4. Reading Comprehension Level Embodiment of "Pagmahay"

\begin{tabular}{|c|c|c|c|c|c|}
\hline $\begin{array}{c}\text { Levels of } \\
\text { Comprehension }\end{array}$ & $\begin{array}{c}\text { No. of } \\
\text { Items }\end{array}$ & $\begin{array}{c}\text { Maximum } \\
\text { Score }\end{array}$ & $\begin{array}{c}\text { Average } \\
\text { Score }\end{array}$ & Percentage & Description \\
\hline Literal & 3 & 9 & 9 & $100 \%$ & Advanced \\
\hline Reorganization & 3 & 9 & 8 & $89 \%$ & Proficient \\
\hline Inference & 3 & 9 & 7 & $78 \%$ & Developing \\
\hline Evaluation & 3 & 9 & 9 & $100 \%$ & Advanced \\
\hline Appreciation & 3 & 9 & 9 & $100 \%$ & Advanced \\
\hline
\end{tabular}

Legend:

$\begin{array}{ll}\text { 90-above } & \text { - Advanced } \\ 85-89 & \text { - Proficient } \\ \text { 80-84 } & \text { - Approaching Proficiency } \\ 75-79 & \text { - Developing } \\ \text { 74-below } & \text { - Beginning }\end{array}$

*The rating scale for the levels of comprehension was based on DepEd Order No. 17, series of 2012.

Table 4 shows that the respondents are advanced in the literal, evaluation, and appreciation levels. They are also proficient in reorganization level. This signifies that the respondents understand the "Balak" because they are able to provide answers to literal questions, evaluate the "Balak", and associate it to their real-life experiences. Having internalized the message of the Balak, they can manage their life to the fullest.

On the other hand, the respondents were developing in inference level which implies that they are not particular of the elements of the "balak" which the writer uses in the "balak". However, they are able to identify the message of the writer. A respondent said: 
"Ang pagbasol naa sa ulahi kanunay ug arun way pagbasol kinahanglan ug saktong plano ug pagpakig-ambit sa kinabuhi ug ang Pag - ampo naa sa kanunay". (Participant 16)

This "Balak" can be considered a tool for assessing comprehension because it facilitates students' reflections and personal connections. The respondents answer eighty percent (80\%) of the questions which denotes that it is not too difficult.

Individuals who contemplated on their regrets were more likely to report reduced life satisfaction and to experience difficulty coping with negative life events ( Lecci et al., 1994; Schwartz et al., 2002).

Furthermore, students are able to realize that failure is just a part of human existence. As a matter of fact, people learn to be firm and strong in all situations bearing in mind that regret is an assurance for a better future.

Table 5. Reading Comprehension Level Embodiment of "Maloibon"

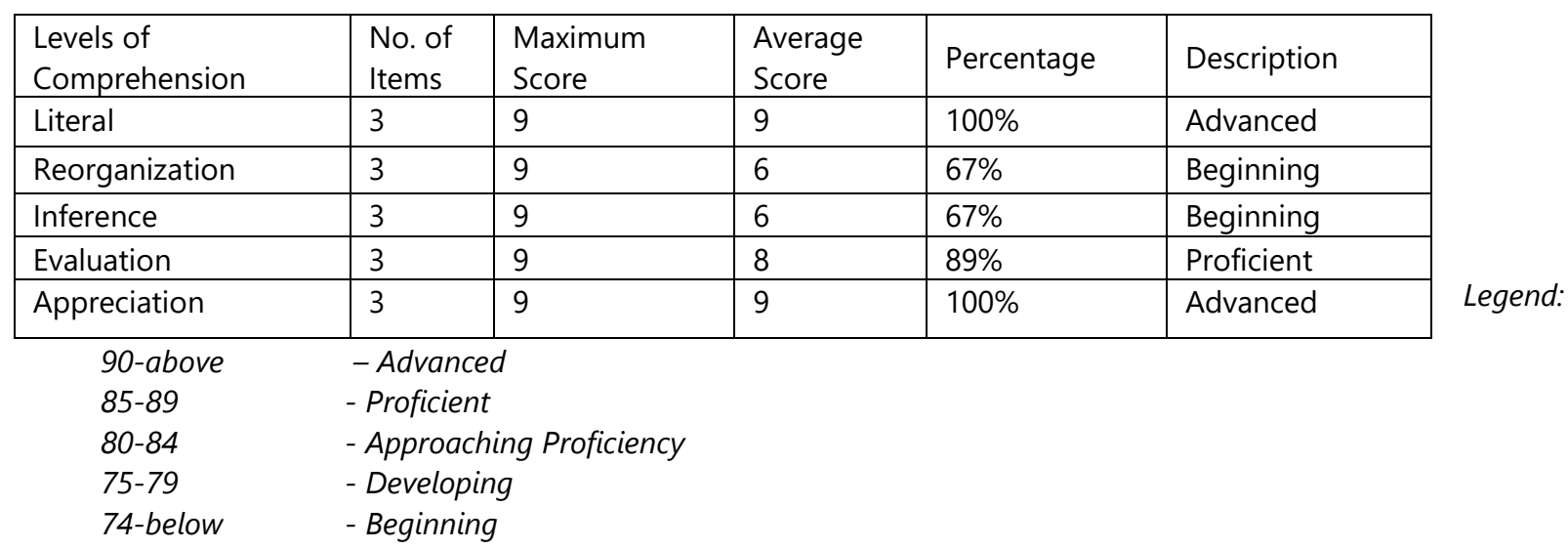

*The rating scale for the levels of comprehension was based on DepEd Order No. 17, series of 2012.

Table 5 indicates that in "Maloibon", the respondents were advanced in Literal and appreciation levels and proficient in the evaluation level. It implies that the respondents achieve a full understanding of the message of the "Balak". The respondents are able to associate with the feelings of the writer; capture important ideas; link and appreciate the essence of the Balak, and relate their observations and experiences in the community to which they belong.

In contrast, the respondents were beginning in the reorganization and inference levels which reveals that in this "Balak" the respondents are low in determining the structure and elements of the "Balak".

This "Balak" is useful in reading and assessing the comprehension of the students because it exposes them to practical scenarios where they can easily respond and share their feelings.

The respondents are able to answer eighty percent (80\%) of the questions which means that they respond correctly to almost all of the questions. Responses of the respondents to the question, What is your response or reaction to the "Balak"?, include:

"MALOIBON is really common for a theme yet it is striking having the power of persuasion, where you can really feel what the writer was feeling. Its message is very visible because of its strong impact; I like how the writer writes it freely yet with boundaries." ( Participant 36)

"I am angry with the woman. Why did she find another man? Why did he leave Moises? It seems like Moises already gave her everything. Why did he leave Moises? She doesn't even care for Moises, as stated in the line "Gipasagdan mo ako nga nag-antos." (Participant 7)

Schoch (2013) said that students were most receptive to new learning when they could connect it to what they already knew. He added that poetry provided a quick and fun way to do this.

Likewise, according to Svinicki (2004), many students believed that good teachers motivated them and these teachers tend to receive high student ratings on items such as the instructor motivated them to do their best work; stimulated their intellectual 
curiosity; encouraged them to express their opinion or experience; and emphasized learning rather than tests or grades. So, because of these, students were able to relate vital information for themselves.

Table 6. Reading Comprehension Level Embodiment of "Pagpanguyab"

\begin{tabular}{|c|c|c|c|c|c|}
\hline $\begin{array}{c}\text { Levels of } \\
\text { Comprehension }\end{array}$ & $\begin{array}{c}\text { No. of } \\
\text { Items }\end{array}$ & $\begin{array}{c}\text { Maximum } \\
\text { Score }\end{array}$ & $\begin{array}{c}\text { Average } \\
\text { Score }\end{array}$ & Percentage & Description \\
\hline Literal & 3 & 9 & 9 & $100 \%$ & Advanced \\
\hline Reorganization & 3 & 9 & 8 & $89 \%$ & Proficient \\
\hline Inference & 3 & 9 & 9 & $100 \%$ & Advanced \\
\hline Evaluation & 3 & 9 & 8 & $89 \%$ & Proficient \\
\hline Appreciation & 3 & 9 & 9 & $100 \%$ & Advanced \\
\hline
\end{tabular}

Legend:

$\begin{array}{ll}\text { 90-above } & \text { - Advanced } \\ 85-89 & \text { - Proficient } \\ 80-84 & \text { - Approaching Proficiency } \\ 75-79 & \text { - Developing } \\ \text { 74-below } & \text { - Beginning }\end{array}$

* The rating scale for the levels of comprehension was based on DepEd Order No. 17, series of 2012.

Table 6 shows that the respondents are advanced in the literal, inference, and appreciations level which denotes that they have a greater understanding of the topic presented and are able to process it well because it talks about courtship. The respondents are also able to express and share their own thoughts and feelings and relate their content with their real-life experiences. Most of the respondents are eager and excited to express their feelings and emotions because they are interested in relationships and courtship which is a part of their journey as teenagers.

"I like this line because I can relate this to my boyfriend who really does everything for me. Even my family doesn't allow me to have a boyfriend, he really visits me in our house just to show his true love to me, even though sometimes I don't like him doing it." (Participant 25)

In the same way, the respondents were proficient in the reorganization and evaluation levels because they were focused more on the content rather than the structures and techniques of the writer in writing the "Balak".

This "Balak", therefore, is an appropriate tool in teaching and assessing reading comprehension because it promotes students' active learning.

Simmons (2014) maintained, "Poetry enables teachers to teach their students how to write, read, and understand any text. Poetry can give students a healthy outlet for surging emotions. Reading original poetry aloud in class can foster trust and empathy in the classroom community, while also emphasizing speaking and listening skills that are often neglected in high school literature classes" (para. 6).

The respondents process and answer the comprehension questions because they find "Pagpanguyab" quite easy, simple, and clear. They are cognizant of the situations reflected in Pagpanguyab which enable them to process its important aspects and ideas.

Cox (2009) stated in the article, 5 Teaching Strategies to keep Class Interesting, "When you create a real-world connection to what students are learning, it will give them a greater understanding of why they need to learn it" (para. 3). This statement implies that in every lesson a teacher is the manager in the classroom. To relate it to the lives of the students is essential to create a better understanding of the lesson.

Table 7. Reading Comprehension Level Embodiment of "Ikaw Ra". 


\begin{tabular}{|c|c|c|c|c|c|}
\hline $\begin{array}{c}\text { Levels of } \\
\text { Comprehension }\end{array}$ & $\begin{array}{c}\text { No. of } \\
\text { Items }\end{array}$ & $\begin{array}{c}\text { Maximum } \\
\text { Score }\end{array}$ & $\begin{array}{c}\text { Average } \\
\text { Score }\end{array}$ & Percentage & Description \\
\hline Literal & 3 & 9 & 9 & $100 \%$ & Advanced \\
\hline Reorganization & 3 & 9 & 8 & $89 \%$ & Proficient \\
\hline Inference & 3 & 9 & 7 & $78 \%$ & Developing \\
\hline Evaluation & 3 & 9 & 8 & $89 \%$ & Proficient \\
\hline Appreciation & 3 & 9 & 9 & $100 \%$ & Advanced \\
\hline
\end{tabular}

Legend:

$\begin{array}{ll}\text { 90-above } & \text { - Advanced } \\ 85-89 & \text { - Proficient } \\ 80-84 & \text { - Approaching Proficiency } \\ 75-79 & \text { - Developing } \\ 74-\text { below } & \text { - Beginning }\end{array}$

*The rating scale for the levels of comprehension was based on DepEd Order No. 17, series of 2012.

Table 7 illustrates that the respondents in the "Balak", "Ikaw Ra," reach advanced in the literal and appreciation levels while they are proficient in the reorganization and evaluation levels. This implies that they admire the situation portrayed in "Ikaw $R a^{\prime \prime}$. They are motivated to determine the writer's intention in writing it. In the same manner, they understood its content. They are able to relate their own experiences in dealing, measuring, and expressing their love to their families, friends, and special someone. Consequently, they are able to magnify their existence and supersede the feelings depicted in "Ikaw $R a$ ".

"Kung ikaw mahigugma kinahanglan gayod usa ra arun dili maguol ang imung hinigugma ug ang pag-respeto anaa sa kanunay arun paghugop sa maong relasyon." (Participant 14)

"Trust and effort are really important when you love a person. You will not forget him/her even when you are with others." (Participant 2)

On the other hand, the respondents are developing at the inference level. They were able to relate important people in their own life to the "Balak".

According to Reeve and Hyungshim (2006), a supportive teaching style that allowed for student autonomy could foster increased student interest, enjoyment, engagement, and performance. Examples of teacher behaviors include listening, giving hints and encouragement, being responsive to student questions, and showing empathy for the student. When teachers exercised those behaviors in the classroom, children were able to catch brighter and challenging ideas that made their lesson interesting.

Table 8. Reading Comprehension Level Embodiment of "Pagtakas sa Bintana"

\begin{tabular}{|c|c|c|c|c|c|}
\hline $\begin{array}{c}\text { Levels of } \\
\text { Comprehension }\end{array}$ & $\begin{array}{c}\text { No. of } \\
\text { Items }\end{array}$ & $\begin{array}{c}\text { Maximum } \\
\text { Score }\end{array}$ & $\begin{array}{c}\text { Average } \\
\text { Score }\end{array}$ & Percentage & Description \\
\hline Literal & 3 & 9 & 9 & $100 \%$ & Advanced \\
\hline Reorganization & 3 & 9 & 9 & $100 \%$ & Advanced \\
\hline Inference & 3 & 9 & 9 & $100 \%$ & Advanced \\
\hline Evaluation & 3 & 9 & 8 & $89 \%$ & Proficient \\
\hline Appreciation & 3 & 9 & 9 & $100 \%$ & Advanced \\
\hline
\end{tabular}

Legend:

$\begin{array}{ll}\text { 90-above } & \text { - Advanced } \\ 85-89 & \text { - Proficient } \\ 80-84 & \text { - Approaching Proficiency } \\ 75-79 & \text { - Developing } \\ 74-\text { below } & \text { - Beginning }\end{array}$

*The rating scale for the levels of comprehension was based on DepEd Order No. 17, series of 2012.

Table 8 shows that the respondents are advanced in literal, reorganization, inference, and in appreciation levels. This reveals that the respondents understand the meaning and the purpose of the "Balak" as well as establish personal connections with it. They 
identify themselves with the writer's personality that permits them to appreciate his work. They are also enlightened by the writer's message in giving emphasis and importance on love and truthfulness.

"Pagtakas sa Bintana" is a good material for reading and assessing the reading comprehension of the students for it is easy to analyze and it can strongly activate their prior acknowledge. This material is engaging to the students for it contains information that they can easily comprehend and this meets their level of experience and understanding.

"Tungod sa kahingawa sa laki siya nahiubos tungod sa wala paghatag ug bili sa gugmang iyang gipaambit, apan dili kita kabuot kay usahay ang tawo lain - lain ang paglantaw, kung ikaw nahigugma sa usa ka tawo andam kang mudawat unsay tubag ug resulta". (Participant 35)

"When you feel in love with someone, you must say it for him/her to be aware of your feelings. If ever it will be neglected by him/her, consider him/her as your inspiration in your life. Time may come he/she will realize that you love him/her and he/she will gradually love you back." (Participant 32)

Brewer (2016, para. 8) said that "picking up poetry, and reading through different excerpts from classic poets can blossom ideas you never knew existed. Reading and writing poetry made one thought of new ideas that could dramatically change the way he or she perceived an old one. It involved processing experiences, visual descriptions, and emotions."

Additionally, Brozo (2005) and McMahon et. al (1996) maintained that teachers needed to create learning activities that were based on topics that were relevant to the students' lives to foster intrinsic motivation. Strategies might include using local samples, teaching with events in the news, using pop culture technology such as iPods, cellphones, Youtube videos, or connecting the subject with the students' culture. These would have a positive impact on their lives.

Table 9. Reading Comprehension Level Embodiment of "Pinangga"

\begin{tabular}{|c|c|c|c|c|c|}
\hline $\begin{array}{c}\text { Levels of } \\
\text { Comprehension }\end{array}$ & $\begin{array}{c}\text { No. of } \\
\text { Items }\end{array}$ & $\begin{array}{c}\text { Maximum } \\
\text { Score }\end{array}$ & $\begin{array}{c}\text { Average } \\
\text { Score }\end{array}$ & Percentage & Description \\
\hline Literal & 3 & 9 & 8 & $89 \%$ & Proficient \\
\hline Reorganization & 3 & 9 & 7 & $78 \%$ & Developing \\
\hline Inference & 3 & 9 & 2 & $22 \%$ & Beginning \\
\hline Evaluation & 3 & 9 & 6 & $67 \%$ & Beginning \\
\hline Appreciation & 3 & 9 & 8 & $89 \%$ & Proficient \\
\hline
\end{tabular}

Legend:

$\begin{array}{ll}\text { 90-above } & \text { - Advanced } \\ 85-89 & \text { - Proficient } \\ 80-84 & \text { - Approaching Proficiency } \\ 75-79 & \text { - Developing } \\ 74-\text { below } & \text { - Beginning }\end{array}$

*The rating scale for the levels of comprehension was based on DepEd Order No. 17, series of 2012.

Table 9 shows that the respondents are proficient in the literal and appreciation levels while developing in the reorganization level. This signifies that they can answer explicit information, associate common information, and build connections to situations that are relevant to their prior knowledge.

Nevertheless, the respondents are at the beginning level in inference and evaluation. This indicates that they are not able to determine the situation, message, figurative language, tone, and theme revealed by the writer in "Pinangga". The results dictate that they are not able to relate entirely to the message and the logical aspect of "Pinangga" because they lack the idea of acquiring a true relationship.

"Sa akong kinabuhi wala ako naka experience nga ako gibiyaanug usa ka laki, I truly love my man because I feel I am loved and respected". (Participant 19)

"I don't relate much to the "Balak" because I wasn't able to experience yet to love and being loved by someone." (Participant 5)

"Pinangga" is also an appropriate material for reading and assessing reading comprehension. However, it is suggested that teachers should build connections before, during, and after reading to deepen their understanding of "Pinangga". 
An article entitled Effective Learning and Teaching published in Science for All Americans Online (1989, para. 4) stated that "concepts were learned best when they were encountered in a variety of contexts and expressed in a variety of ways. By doing so, there would be sufficient opportunities for the concepts to be embedded in students' knowledge system."

To increase students' knowledge in the teaching-learning process, there must be an application of concepts introduced by teachers in the classroom.

Table 10. Reading Comprehension Level Embodiment of "Dughanng Samaran".

\begin{tabular}{|c|c|c|c|c|c|}
\hline $\begin{array}{c}\text { Levels of } \\
\text { Comprehension }\end{array}$ & $\begin{array}{c}\text { No. of } \\
\text { Items }\end{array}$ & $\begin{array}{c}\text { Maximum } \\
\text { Score }\end{array}$ & $\begin{array}{c}\text { Average } \\
\text { Score }\end{array}$ & Percentage & Description \\
\hline Literal & 3 & 9 & 9 & $100 \%$ & Advanced \\
\hline Reorganization & 3 & 9 & 8 & $89 \%$ & Proficient \\
\hline Inference & 3 & 9 & 4 & $44 \%$ & Beginning \\
\hline Evaluation & 3 & 9 & 8 & $89 \%$ & Proficient \\
\hline Appreciation & 3 & 9 & 9 & $100 \%$ & Advanced \\
\hline
\end{tabular}

Legend:

$\begin{array}{ll}\text { 90-above } & \text { - Advanced } \\ 85-89 & \text { - Proficient } \\ 80-84 & \text { - Approaching Proficiency } \\ 75-79 & \text { - Developing } \\ 74-\text { below } & \text { - Beginning }\end{array}$

*The rating scale for the levels of comprehension was based on DepEd Order No. 17, series of 2012.

Table 10 shows that the respondents in Dughang Samaran" are advanced in the literal and appreciation levels and proficient in reorganization and evaluation levels. This indicates that they understand the writer's purpose and intentions; recognize important details; and connect the message of "Dughang Samaran" to their painful life experiences with their families, friends, and loved ones. A respondent asserted that, "Sakit kaajo kung ikaw biyaan sa imung mga mahal sa buhay, kung walay mi - care nimu, ilabi na sa imung hinigugma nga nagpalajo nimu tungod kay naa na sijay laing hinigugma." (Participant 15)

On the contrary, the respondents are in the beginning level for inference which means that they are not able to determine the main idea of "Dughang Samaran" as well as the types of figurative language used by the writer. As seen in their responses, they were not able to acquire a deeper understanding of the "Balak" because they just brought the situations into literal understanding.

This material can also be considered the right tool in developing reading comprehension because it allows students' minds to work and think. This develops and enhances students' reading ability and comprehension.

Furthermore, Effective Learning and Teaching Science for All Americans Online (1990) conveyed that students grew in selfconfidence as they experienced success in learning, just as they lost confidence in the face of repeated failure. Thus, teachers need to provide students with challenging but attainable learning tasks and help them succeed. From this, students learn to cope with experiences where they can blend and meet life's expectations.

Brewer (2016, para. 9) also conveyed that "Poetry is typically short but largely emotional. Writers get in touch with sentiments they might not have known they had until it was down on paper. Depression and anxiety are among the top two mental illnesses being treated with Bibliotherapy, and through poetry, one can start to understand the hindrances and blocks being formed around their mind. Expressing how one feels is difficult. It was found that poetry is one of the best outlets."

Table 11. Overall Reading Comprehension Levels.

\begin{tabular}{|c|c|c|c|c|}
\hline $\begin{array}{c}\text { Levels of } \\
\text { Comprehension }\end{array}$ & Questions & Collected Local “Balak" & Description \\
\hline
\end{tabular}




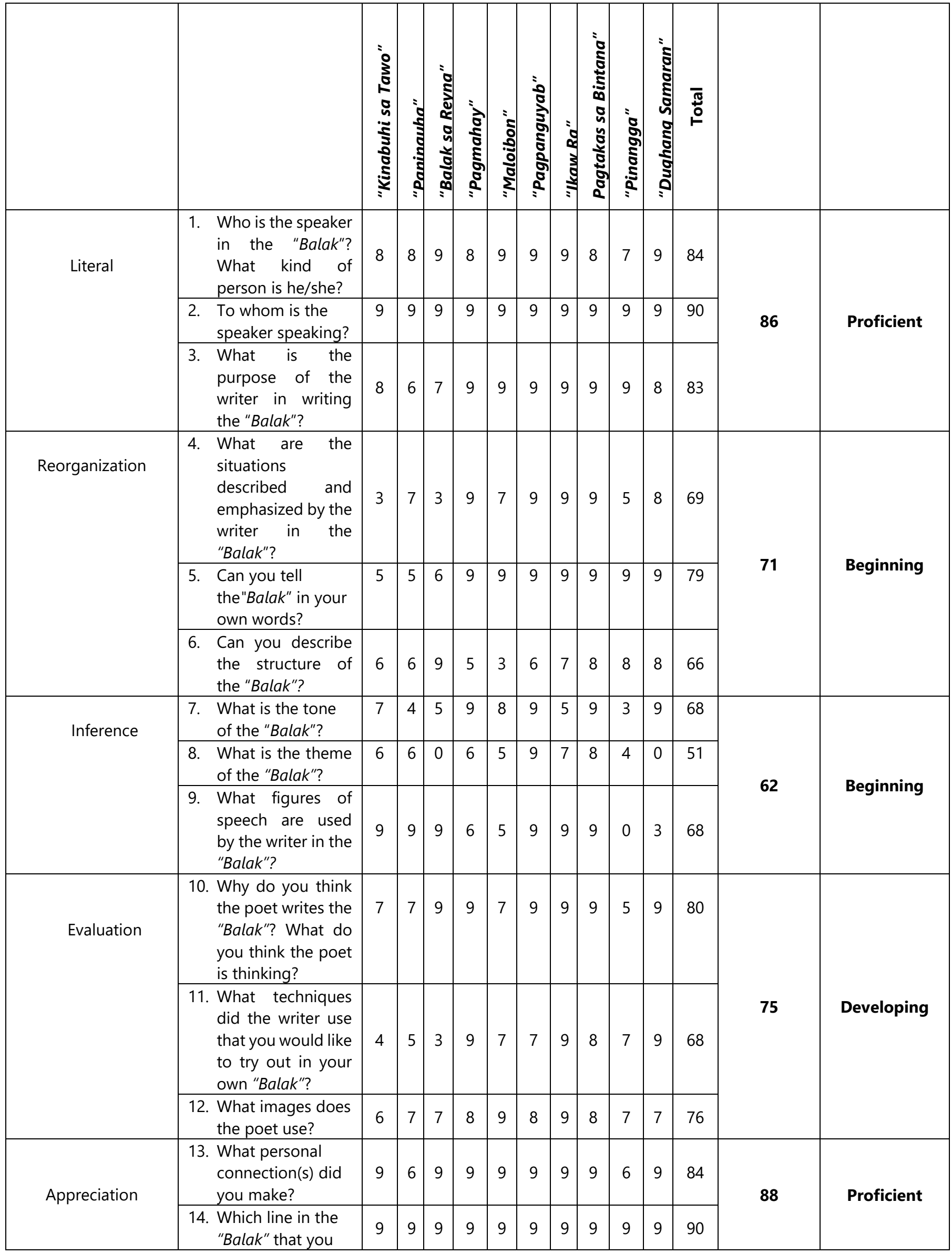




\begin{tabular}{|l|l|l|l|l|l|l|l|l|l|l|l|l|l|l|}
\hline & $\begin{array}{l}\text { consider your } \\
\text { favorite line or } \\
\text { striking line? }\end{array}$ & & & & & & & & & & & & \\
\hline & $\begin{array}{l}\text { 15. What is your } \\
\text { response/reaction } \\
\text { to the "Balak"? }\end{array}$ & 9 & 9 & 9 & 9 & 9 & 9 & 9 & 9 & 9 & 90 & 9 \\
\hline
\end{tabular}

Legend:

$\begin{array}{llll}90-\text {-above } & \text { - Advanced } & 75-79 & \text { - Developing } \\ 85-89 & \text { - Proficient } & 74-\text { below } & \text { - Beginning } \\ 80-84 & \text { - Approaching Proficiency } & \end{array}$

80-84 - Approaching Proficiency

*The rating scale for the levels of comprehension was based on DepEd Order No. 17, series of 2012.

Table 11 reveals the respondents' level of comprehension using the "Balak" as a tool for reading. Based on the results, the respondents were proficient in responding to literal and appreciative levels of comprehension. This implies that if the students knew the literal or implied meaning of the text, they could interact with the text and connect and relate its content to their own personal views, experiences, and ideas. In effect, it permits them to value and appreciate the importance and meaning of the text.

However, the respondents were in the developing stage at the evaluation level. This denotes that the respondents evaluate and process the information stated in the "Balak". It can be understood that they are in a developing stage because they are not exposed to"Balak". In this case, they are not aware of what should be and can be incorporated in the "Balak". Furthermore, the respondents were in the beginning in the reorganization and inference levels which denote that the respondents find it difficult to restate and create their new version of the "Balak". They do not know how to write a Balak specifically on its structure, tone, theme, and figurative language. As a result, they have difficulty in determining it in the "Balak".

In a general sense, the "Balak" can be a great tool for reading and assessing the reading comprehension levels of the students. It contains ideas and pieces of information which enable the students' minds to focus, think, and do the task required. It can also develop their cognitive and critical thinking skills because it allows them to evaluate, criticize, and express their feelings and opinions. Equally important is that it is a great tool where they can appreciate and value literature.

People had a fundamental need to establish a connection with others. In an academic environment, Colibaba, et. al (2014, p. 422) stressed that "students who feel they 'belong' had a higher degree of intrinsic motivation and academic confidence. Students' sense of belongingness was fostered by an instructor who demonstrated warmth and openness, encourages student participation; was enthusiastic, friendly, and helpful, and was organized and prepared for class. This is what students hope for a perfect classroom environment."

\section{Conclusion}

It has been concluded that the ten local "Balaks" have the embodiments of the levels of comprehension with which the students were proficient in the literal level, beginning in both the reorganization and inference levels, developing in the evaluation level, and proficient in the appreciation level. Although the ten "Balaks" contained the embodiments of the levels of reading comprehension and could be used as teaching tools in reading, more activities in the reorganization and inferential levels are to be emphasized. Moreover, it is recommended that (1) Teachers should apply contextualization and localization in the teachinglearning process through the use of local literary pieces that fit the levels, interests, and abilities of the learners. (2) Collection of local literary pieces should be done to further support the Department of Education's endeavor on contextualization and localization while preserving the rich culture of the communities. (3) Teachers should be aware that local literary pieces are good sources to develop students' reading abilities. It can also be a good springboard for teaching strategies, reading comprehension assessments, and activities that encourage discussions and stimulate imaginative responses leading to well-rounded and interesting student interactions. (4) The teaching blueprint of this study should be used as supplementary materials in developing the reading comprehension levels of the students.

\section{References}

[1] Aguilar, E. (2013). Five Reasons Why We Need Poetry in Schools. Edutopia. http://www. edutopia. org/blog/five-reasons-poetry-neededschools-elena-aguilar (accessed June 30, 2014).

[2] Al-Khateeb, O. S. M., \& Idrees, M. W. K. (2010). The impact of using KWL strategy on grade ten female students' reading comprehension of religious concepts in Ma'an city. European Journal of Social Sciences, 12(3), 471-489. 
[3] Baumann, J. F., Seifert-Kessell, N., \& Jones, L. A. (1992). Effect of think-aloud instruction on elementary students' comprehension monitoring abilities. Journal of Reading Behavior, 24(2), 143-172.

[4] Best, R. M., Floyd, R. G., \& Mcnamara, D. S. (2008). Differential competencies contributing to children's comprehension of narrative and expository texts. Reading psychology, 29(2), 137-164.

[5] Brewers, C. (1915). MESSRS. CROWLEY. Reader's Index and Guide, 16(3), 49.

[6] Dewitz, P., Carr, E. M., \& Patberg, J. P. (1987). Effects of inference training on comprehension and comprehension monitoring. Reading Research Quarterly, 99-121.

[7] Hughes, J. (2007). Poetry: A powerful medium for literacy and technology development.

[8] McCarthy, C. Poetry in translation. Lesson Plan published by the Academy of American Poets.

[9] McHale, C. R. (2015). Facilitating the challenge back into Adventure Challenge: the effects of facilitation of adventure-based learning experiences on elementary student's social skills and intra-personal attitudes.

[10] Magliano, J. P., Todaro, S., Millis, K., Wiemer-Hastings, K., Kim, H. J., \& McNamara, D. S. (2005). Changes in reading strategies as a function of reading training: A comparison of live and computerized training. Journal of Educational Computing Research, 32(2), $185-208$.

[11] McNamara, D. S., Ozuru, Y., Best, R., \& O’Reilly, T. (2007). The 4-pronged comprehension strategy framework. Reading comprehension strategies: Theories, interventions, and technologies, 465-496.

[12] Ozdemir, A. S. (2009). The effect of reading comprehension abilities primary school students over their problem solving achievement. Reading Improvement, 46(2), 88-99.

[13] Richardson, N. (2010). Guided reading strategies for reading comprehension

[14] Singh, M. P. (2005). Quote Unquote (A Handbook of Quotations). Lotus Press.

[15] Simmons, A. (2014). Why teaching poetry is so important. The Atlantic.

[16] Watts, A. (2016). Exploring Poetry with Young Children: Sharing and creating poems in the early years. Routledge. 